\title{
Enterpreneurship Capacity Building (ECB) New Normal dan Edukasi Pengelolaan Sumber Daya Desa untuk Mendukung Ketahanan Ekonomi Masyarakat di Tengah Pandemi
}

\author{
Imran Rosman Hambali ${ }^{1}$, Abdulrahim Maruwae ${ }^{2}$ \\ ${ }_{1,2}$ Universitas Negeri Gorontalo, Jl. Jend. Sudirman No. 6 Dulalowo Timur, Kota \\ Tengah, Kota Gorontalo, Indonesia \\ email: imranhambali@ung.ac.id, uli@ung.ac.id
}

\begin{abstract}
Abstrak
Pengembangan Potensi Desa Pesisir di Tengah Pandemi Covid-19 Melalui Pemberdayaan Masyarakat dengan Metode Enterpreneurship Capacity Building (ECB) New Normal dan Edukasi Pengelolaan Sumber Daya Desa. Kuliah Kerja Nyata Tematik Lembaga Pengabdian Masyarakat Universitas Negeri Gorontalo Tahun 2020. KKN Tematik ini bertujuan mengidentifikasi potensi strategis desa dan mengedukasi masyarakat terkait potensi desa yang dimiliki dan dapat dimanfaatkan sebagai sumber pendapatan dalam mendorong ekonomi masyarakat. Selain itu, memberikan edukasi kewirausahaan era normal baru diberbagai sektor potensial yang telah teridentifikasi terutama sektor pertanian, serta memberikan edukasi pengelolaan sumber daya desa dalam mendukung peningkatan ekonomi produktif di desa. Di samping itu juga, menggiatkan kegiatan produktif lainnya seperti mengembangkan budaya literasi desa dengan membentuk komunitas literasi. Target dan luaran yang dicapai dalam pelaksaaan Program KKN Tematik ini yaitu terbentuk program pengembangan potensi desa melalui metode Entrepreneurship Capacity Building (ECB) new normal dan edukasi pengelolaan sumber daya desa, terbentuknya pola pikir masyarakat dalam meningkatkan produktivitas usahanya walaupun pada masa pandemi dengan informasi yang telah diperoleh mengenai strategi peningkatan kapasitas wirausaha di era new normal, selain itu berbagai kelompok masyarakat baik aparat desa, pengelola BUMDes, kelompok usaha telah dibekali pengetahuan tentang pencatatan keuangan yang ideal dan terstandarkan.
\end{abstract}

Kata Kunci: Enterpreneurship Capacity Building (ECB), Sumber Daya Desa

\begin{abstract}
The Development of Potential coastal Village in the middle of Covid-19 pandemic through community empowerment with Entrepreneurship Capacity Building (ECB) in New Normal Era and education of management village resources method. Student Service Program (KKN). Universitas Negeri Gorontalo, 2020. This program aims to identified village strategic program and education on community related to potential of the village, that could be used as income resources to enhance economy of community. Besides, this program is also provide an entrepreneurial education to community through potential sectors has been identified especially in agriculture sector, and giving an education about management of village resources in order to support the enhance of productive economy of community facing a new normal era. The target and outcome that could be achieve in this program is (1) to establish potential development program of the village using Entrepreneurship Capacity Building (ECB) and education of management village resources method; (2) to
\end{abstract}


establish community mindset in order to enhance their business productivity; (3) to equip groups such as management BUMDes, Village officers, and community about how to arrange an ideal financial report.

Kata Kunci: Entrepreneurship Capacity Building (ECB), New Normal, village resources

(C) 2021 Imran Rosman Hambali, Abdulrahim Maruwae Under the license CC BY-SA 4.0

Correspondence author: Abdulrahim Maruwae, iuli@ung.ac.id, Gorontalo, Indonesia

\section{PENDAHULUAN}

Letak georafis Indonesia yang terdiri dari ribuan pulau menempatkannya sebagai sebagai salah satu poros maritim dunia. Dengan sebaran sekitar 17.500 pulau dan memiliki garis panjang pantai terpanjang kedua di dunia (Solihin, 2010) menggambarkan adanya potensi kekayaan alam yang melimpah. Keadaan ini menjadi anugerah bagi masyarakatnya, dengan segala potensi sektor kelautan dan perikanan dapat dimanfaatkan sebagai sumber pencaharian.

Potensi wilayah yang dimiliki jika dikelola dan dimanfaatkan dengan baik dapat meningkatkan taraf hidup masyarakat daerah pesisir. Pengembangan wilayah pesisir dengan memperhatikan potensi kelautan dan pariwisata diharapkan dapat meningkatkan kesejahteraan masyarakat. Muhamad (2009) menyatakan bahwa kondisi nelayan di pesisir pantai masih bergelut dengan kemiskinan, penghasilan yang didapat oleh buruh nelayan dan nelayan kecil tidak bisa mencukupi kebutuhan sehari-hari. Oleh karena itu, perlu ada upaya dalam memberdayakan masyarakat seperti mengedukasi pola pikir dan keterampilan wirausaha, memperkuat nilai-nilai lokal genius, maupun mengembangkan potensi pariwisata dan pengelolaan hasil laut yang benilai tambah, dan pengembangan sektor lainya di kawasan pesisir. 
Monano merupakan salah satu kecamatan di kabupaten Gorontalo Utara Provinsi Gorontalo yang terletak di bagian pesisir pantai. Adapun jumlah penduduk Kecamatan Monano berdasarkan data yang diperoleh pada tahun 2019 adalah 6.807 jiwa yang tersebar dalam 10 Desa. Sebagai salah satu daerah pesisir di Gorontalo, Monano memiliki banyak potensi dengan prospek yang sangat menjanjikan bagi pengembangan ekonomi kawasan pesisir. Baik dalam pengembangan sektor perikanan, sektor pertanian, sektor pariwisata, maupun sektor lainnya yang mengakomodasi potensi wilayah. Dalam mendukung pengembangan diberbagai sektor perlu ada upaya pemberdayaan bagi masyarakat terutama dalam kondisi pandemi seperti saat ini yang berdampak pada ekonomi masyarakat.

Kondisi ketidakpastian ekonomi seperti saat ini tentu sangat memukul pendapatan masyarakat, terutama bagi masyarakat dengan hanya bergantung pada hasil pertanian dan usaha harian. Sebagai upaya membangkitkan kembali aktivitas dan interaksi ekonomi masyarakat serta untuk mengembangkan potensi dan sumber daya desa di tengah pandemi covid-19, terdapat beberapa langkah alternatif yang dapat ditempuh. Dimulai dari mengidentifikasi potensi dan sumber daya desa, selanjutnya pada segmen wirausaha juga mengidentifikasi usaha mandiri masyarakat yang sudah berjalan untuk dilakukan pendampingan dalam proses pemasarannya dengan memperhatikan perilaku hidup bersih dan sehat serta memaksimalkan penggunaan media sosial dan media cetak.

Segmen lanjutan wirausaha berfokus pada potensi sektor pertanian dengan memanfaatkan hasil pertanian untuk dijadikan produk wirausaha seperti panganan. Pengelolaan panganan tersebut 
memberikan nilai tambah bagi pendapatan masyarakat. Di samping itu, dapat memanfaatkan potensi teridentifikasi lainnya yang bernilai ekonomi dengan tetap memperhatikan protokol kesehatan dan perilaku hidup bersih dan sehat (PHBS).

Mengakomodasi berbagai langkah yang telah dijelaskan di atas, perlu diberikan ruang pemberdayaan kepada masyarakat yang dikemas dalam Enterpreneurship Capacity Building (ECB) new normal. Nurjaya, dkk (2017:21) mengungkapkan bahwa metode ECB berkaitan erat dengan kemampuan berwirausaha dari masyarakat yang diharapkan dapat: 1) memberikan wawasan, sikap dan keterampilan usaha, 2) memberikan peluang untuk membuka usaha dan pemberian modal, 3) memonitoring dan mengevaluasi bagaimana pengembangan usahanya. Dalam kegiatan pengabdian pada masa pandemi covid-19 ini, juga membekali masyarakat dengan kemampuan berwirausaha di era industri 4.0 dan new normal. Sehingga metode ECB sebelumnya dikembangkan lagi dengan harapan dapat: 4) memberikan wawasan dan keterampilan dalam mengembangkan bisnis digital berbasis potensi daerah, 5) memberikan wawasan dan penguatan mengenai manfaat protokol kesehatan dan PHBS dalam menjalankan bisnis.

Guna mendukung program di atas agar bisa survive serta pengembangan potensi desa dapat dikawal secara berkelanjutan, perlu mendapatkan dukungan dari pemerintah setempat. Dalam hal ini pemerintah desa perlu mempertimbangkan porsi alokasi anggaran dana desa untuk kegiatan ekonomi yang produktif di desanya. Menjembatani langkah tersebut, dapat diberikan ruang edukasi bagi aparat desa dalam bentuk sosialisasi model pengelolaan alokasi dana desa. Model yang dapat disosialisasikan yaitu Model Pengelolaan 
Alokasi Dana Desa dalam Peningkatan Kegiatan Ekonomi Produktif di Desa (Hambali dan Niode: 2018). Temuan penelitian yang dilakukan oleh Hambali dan Niode (2018:1) membuktikan bahwa Dana Desa mampu menjadi daya ungkit terhadap perekonomian desa untuk berkembang maju dan meningkatkan kesejahteraan masyarakat di Kabupaten Bone Bolango. Berdasarkan analisis di atas perlu dilaksanakan Program Pemberdayaan Masyarakat dengan Metode Enterpreneurship Capacity Building (ECB) New Normal dan Edukasi Pengelolaan Sumber Daya Desa dengan diharapkan mampu menjawab fenomena yang telah diuraikan di atas.

\section{METODE PELAKSANAAN}

Desa yang menjadi mitra pelaksanaan KKN Tematik tahun 2020 yakni Desa Mokonowu Kecamatan Monano Kabupaten Gorontalo Utara. Desa Mokonowu memiliki Sumber Daya Manusia cukup terampil serta berusaha untuk mempelajari segala sesuatu. Di Desa ini terdapat beberapa masyarakat yang memiliki UMKM. Masyarakat di Desa ini

sebagian besar merupakan petani jagung. Namun jagung yang dihasilkan langsung dijual digudang karena kurangnya pengetahuan dan keterampilan petani, bagaimana cara mengolah jagung tersebut menjadi sebuah produk yang bernilai ekonomi. Masyarakat juga masih terkendala dengan kurangnya pengetahuan dalam memasarkan produk secara digital (online) dan terkendala sulitnya jaringan internet yang mendukung proses pemasaran produk secara digital (online) sehingga masyarakat mengalami kesulitan dalam proses pemasaran produk yang dimiliki.

Metode yang digunakan dalam program KKN Tematik ini dengan memperhatikan kondisi di atas yaitu Enterpreneurship Capacity Building 
(ECB) yang di dalamnya berisi workshop, pelatihan dan pendampingan pengolahan potensi desa dan penguatan usaha di era new normal. Selanjutnya, menggunakan metode edukasi model pengelolaan sumber daya desa dalam peningkatan kegiatan ekonomi produktif di desa.

Adapun jenis kegiatan yang dilaksanakan antara lain: mengidentifikasi potensi desa dan penyusunan rencana pengembangan potensi Desa Mokonowu; (2) edukasi pengelolaan usaha di era new normal (ECB); (3) edukasi pengelolaan sumber daya desa dalam mendukung peningkatan kegiatan ekonomi produktif di desa; (4) optimalisasi dan pendampingan gerakan literasi desa.

\section{HASIL DAN PEMBAHASAN}

\section{Hasil}

Realisasi dalam pelaksanaan Program Pemberdayaan Masyarakat dengan Metode Enterpreneurship Capacity Building (ECB) New Normal dan Edukasi Pengelolaan Sumber Daya Desa adalah sebagai berikut:

1. Identifikasi potensi desa dan penyusunan rencana pengembangan potensi Desa Mokonowu
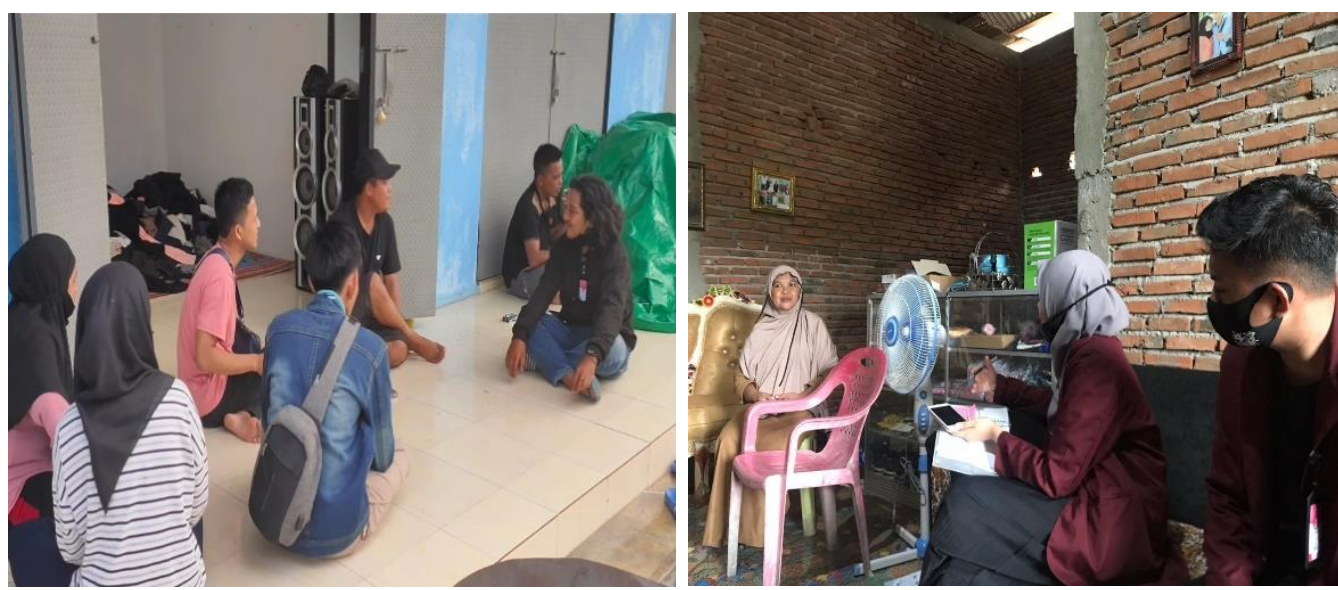
2. Edukasi strategi pengelolaan usaha di era new normal

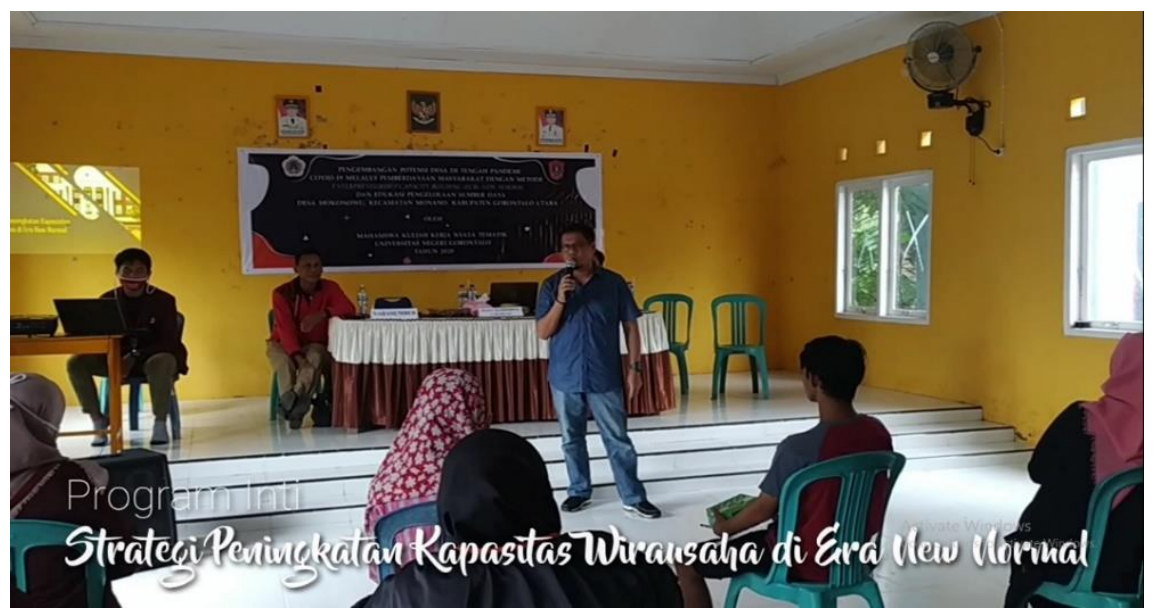

3. Edukasi pengelolaan potensi sektor pertanian

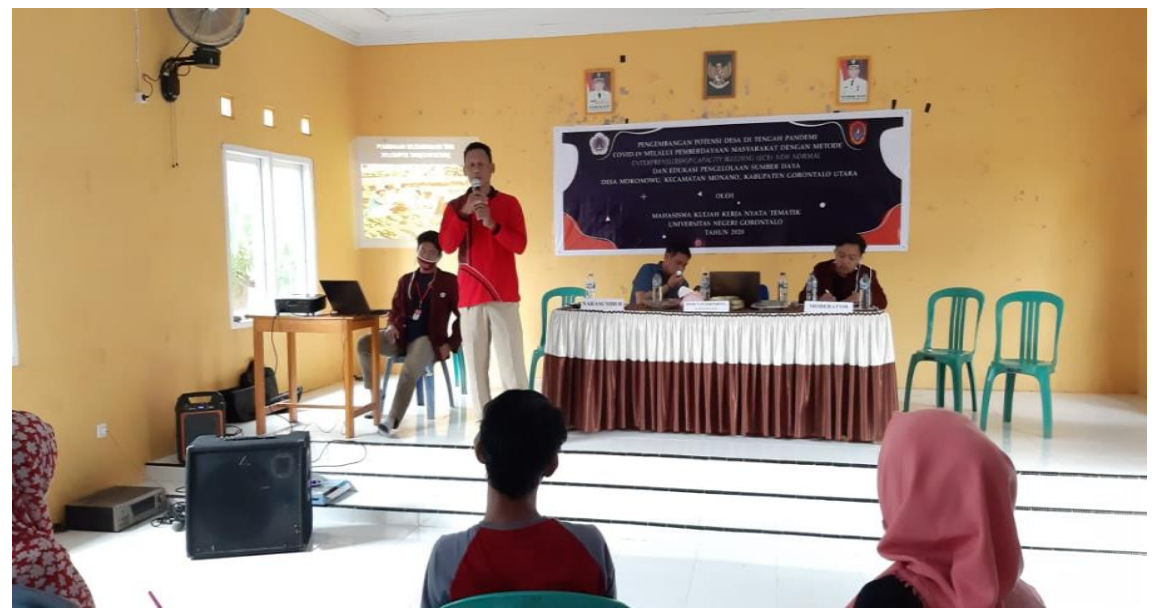

4. Edukasi pencatatan keuangan di Desa

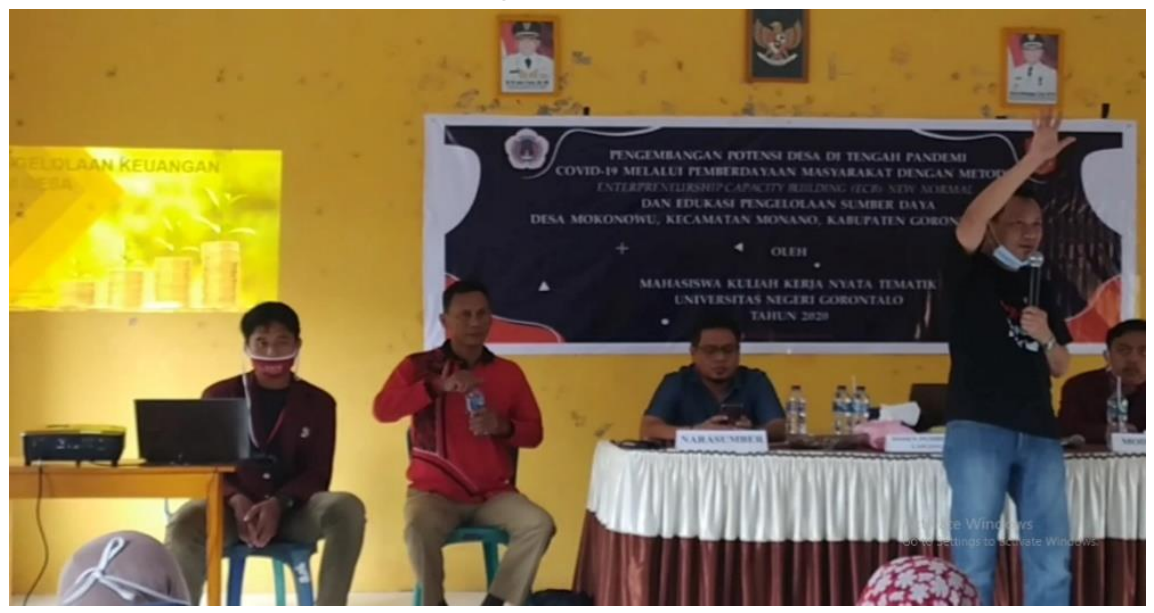


5. Optimalisasi dan pendampingan gerakan literasi desa
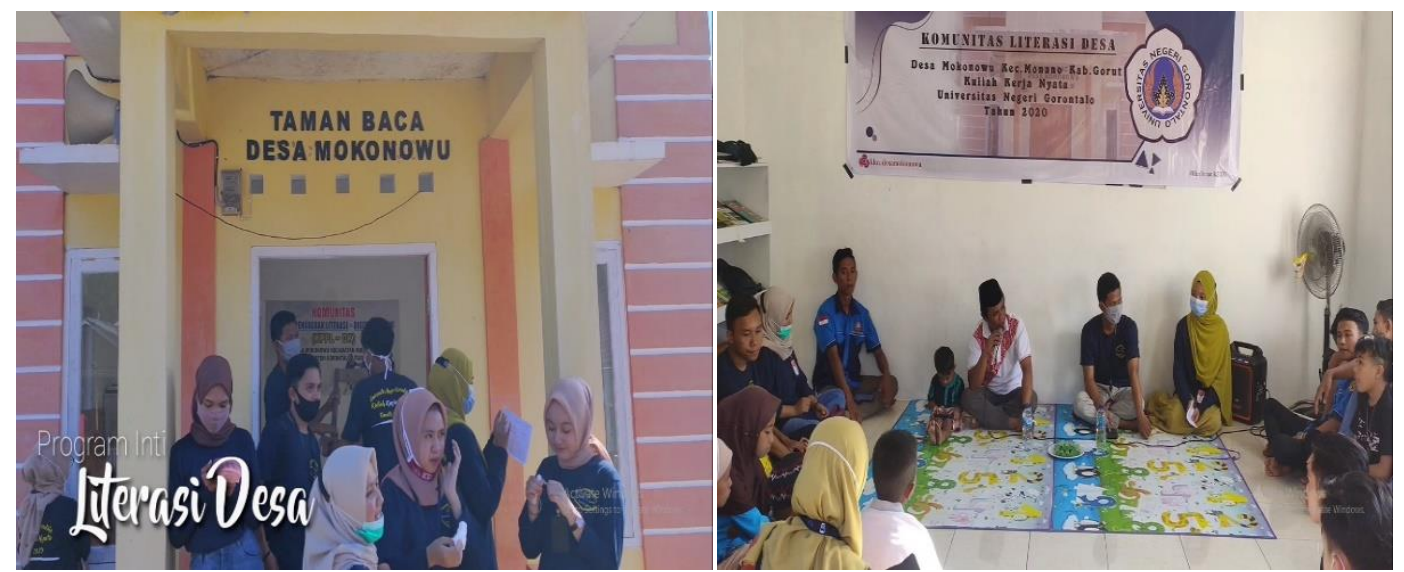

Tahapan pelaksanaan program diawali dengan koordinasi yang dilakukan oleh kelompok mahasiswa (divisi tugas) yang telah dibagi dengan kepala desa, untuk memperoleh data dan informasi desa. Setelah berkonsultasi dengan pemerintah desa, tokoh masyarakat, karang taruna, selanjutnya mahasiswa diarahkan untuk melakukasi observasi ke beberapa tempat dan dusun serta memantau perkembangan kelompok usaha.

Data yang diperoleh selanjutnya dibahas dalam rapat untuk memperoleh gambaran potensi desa yang disampaikan selanjutnya pada saat pertemuan monev dengan dosen pembimbing. Dari beberapa gambaran yang disampaikan pada saat monev, pembimbing mengarahkan untuk membahas penyusunan pengembangan profil desa dan mengidentifikasi kelompok usaha yang menjadi sasaran pada saat kegiatan inti. Rumusan program yang telah dibahas selanjutnya dipaparkan kepada masyarakat melalui pemerintah desa, kelompok usaha, pengelola BUMDes dan karang taruna. 


\section{Pembahasan}

Realisasi kegiatan inti program KKN Tematik Desa Mokonowu dikemas dalam beberapa kegiatan pemberdayaan meliputi kegiatan workshop wirausaha yang menghadirkan narasumber ahli dari unsur akademisi. Fokus pembahasan terkait strategi peningkatan kapasitas wirausaha di era new normal sebagaimana tajuk tema KKN yang diangkat. Pada kegiatan dihadiri oleh pemerintah desa, kelompok usaha, pengelola BUMDes, tokoh masyarakat dan unsur karang taruna. Di samping itu, dalam rangka memaksimalkan peluang potensi sektor pertanian yang teridentifikasi merupakan sektor potensial desa maka dalam kegiatan inti juga dihadirkan narasumber dari Dinas Pertanian Kabupaten Gorontalo Utara. Fokus pembahasan terkait pengelolaan potensi sektor pertanian dan pembinaan kelembagaan tani.

Bertemali dengan tajuk KKN, permintaan dari pemerintah desa kepada mahasiswa agar memberikan ruang edukasi dan pelatihan pencatatan keuangan bagi pengelola BUMDes, Kelompok Usaha, dan aparat desa. Sehingga dalam rangkaian kegiatan inti, turut direalisasikan permintaan tersebut sekaligus membuka ruang diskusi terkait pengelolaan alokasi dana desa sebagaimana yang disentil dalam pembahasan latar belakang.

Ruang pemberdayaan yang dikemas melalui kegiatan workshop dan pelatihan kepada kelompok usaha dan masyarakat lainnya turut mendukung strategi pemerintah dalam menstimulasi pertumbuhan ekonomi pada masa pandemi melalui dukungan terhadap sektor Usaha Mikro, Kecil dan Menengah (UMKM). Farida, Widianti, dan Sunandar, 2015 dalam penelitiannya mengungkapkan bahwa pemberdayaan 
UMKM diharapkan mampu menggenjot akselerasi pertumbuhan ekonomi.

Hasil identifikasi potensi desa juga ditemukan adanya riwayat aktivitas literasi yang pernah digalakkan di Desa Mokonowu. Merespon hal tersebut, program $\mathrm{KKN}$ diperkuat dengan menggiatkan gerakan literasi desa yang digalakan setiap pekan selama pelaksanaan KKN dengan sasaran anak-anak dari usia dini hingga remaja. Penguatan yang diberikan dimulai dari belajar membaca, belajar bahasa inggris, tilawah dan bidang lainnya sesuai dengan disiplin ilmu dari mahasiswa.

Hasil yang dicapai dari seluruh rangkaian Program KKN Tematik di Desa Mokonowu, baik kegiatan inti maupun kegiatan tambahan diantaranya: 1). Terwujudnya program pengembangan potensi desa melalui metode Entrepreneurship Capacity Building (ECB) new normal dan edukasi pengelolaan sumber daya desa di Desa Mokonowu yang dilaksanakan oleh mahasiswa, dosen pembimbing lapangan, pemerintah desa, karang taruna, kelompok usaha, pengelola BUMDes dan masyarakat; 2). Terbentuknya pola pikir masyarakat dalam meningkatkan produktivitas usahanya walaupun pada masa pandemi dengan informasi yang telah diperoleh mengenai strategi peningkatan kapasitas wirausaha di era new normal; 3). Terbentuknya komunitas literasi desa yang diharapkan secara konsisten menggiatkan gerakan literasi dengan pemanfaatan taman baca dan segala fasilitasnya yang telah ditata.

Melalui program KKN Tematik ini juga, 4). berbagai kelompok masyarakat baik aparat desa, pengelola BUMDes, kelompok usaha juga dibekali pengetahuan tentang pencatatan keuangan yang ideal dan terstandarkan; serta, 5). semakin meningkatnya kesadaran dari 
masyarakat mengenai pentingnya menjaga kebersihan dalam mencegah bakteri dan virus serta aktivitas berolah raga dapat meningkatkan imunitas tubuh jika rutin dilakukan.

\section{KESIMPULAN}

Program Pemberdayaan yang telah dilaksanakan kepada masyarakat Desa Mokonowu terdiri dari kegiatan inti dan kegiatan tambahan meliputi:1). Identifikasi potensi desa dan penyusunan rencana pengembangan potensi Desa Mokonowu, 2). Edukasi Strategi Pengelolaan Usaha di Era New Normal, 3). Edukasi Pengelolaan Potensi Sektor Pertanian, 4). Edukasi Pencatatan Keuangan di Desa, dan 5). Optimalisasi dan pendampingan gerakan Literasi Desa serta Program tambahan yakni Sorga Desa (Seni dan Olah Raga). Partisipasi dan dukungan masyarakat cukup tinggi, dimana masyarakat turut aktif dalam pelaksanaan program. Hal ini dapat memberikan manfaat bagi masyarakat dalam mengembangan potensi yang dimiliki baik untuk dirinya maupun untuk daerahnya.

Program yang terealisasi tentu tidak luput dari kendala dan hambatan dalam pelaksanaannya, seperti sulitnya mengumpulkan masyarakat untuk mengikuti berbagai kegiatan. Padatnya aktivitas pekerjaan masyarakat, terlebih yang berprofesi sebagai petani membuat partisipasinya dalam berbagai kegiatan terlihat kurang konsisten. Dengan harapan semoga warga masyarakat dapat terus bergerak melaksanakan keberlanjutan program yang telah dilaksanakan walaupun mahasiswa KKN telah kembali ke Universitas Negeri Gorontalo. 


\section{UCAPAN TERIMA KASIH}

Ucapan terima kasih disampaikan kepada;

1. Universitas Negeri Gorontalo atas dukungan dana sehingga program pengabdian ini bisa terlaksana.

2. Pemerintah Desa Mokonowu Kecamatan Monano yang telah berkenan memfasilitasi ruang pemberdayaan bagi kelompok usaha, aparat desa, pengelola BUMDes sebagai mitra dalam kegiatan ini.

\section{REFERENSI}

Badan Pusat Statistik, (2019). Kecamatan Monano Dalam Angka 2019, Kwandang: BPS Gorontalo Utara

Farida, Ida. Widianti, Hesti. Sunandar. (2015). "Analisis Pengaruh Usaha Mikro Kecil dan Menengah (UMKM) Pengraji Shuttlecock Dalam Meningkatkan Pendapatan". Monex: Journal Research Accounting Politeknik Tegal. Vol 4. No 2.

Hambali, I. R., Noide, I. (2018). Management Model of Village Fund Allocation in Enhancing the Village's Productive Economic Activities, Macrothink Institute, Business and Economic Research, Vol. 8 (4)

Muhamad, Fadel. (2009). Reinventing Local Government: Pengalaman dari Daerah, Jakarta: Gramedia

Nurjaya, I Gede, dkk. (2017). Pemberdayaan Masyarakat Dalam Pengembangan Ekonomi Kreatif Berbasis Tri Harta Di Desa Binaan Abang Batu Dinding Kecamatan Kintamani Kabupaten Bangli, International Journal of Community Service Learning, Vol. 1 (1) 17-25

Solihin, Akhmad. (2010). Politik Hukum Kelautan dan Perikanan, Bandung: Nuansa Aulia. 